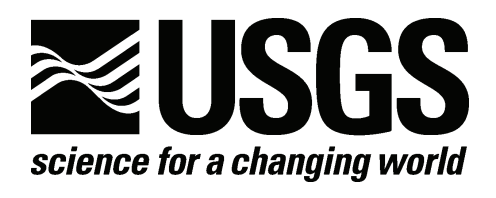

\title{
Seismic Constraints and Coulomb Stress Changes of a Blind Thrust Fault System, 2: Northridge, California
}

By Ross S. Stein ${ }^{1}$ and Jian Lin ${ }^{2}$

2006

Open-File Report 2006-1158

${ }^{1}$ U.S. Geological Survey, Menlo Park, Calif.

2 Woods Hole Oceanographic Institution, Woods Hole, Mass.

U.S. Department of the Interior

U.S. Geological Survey 


\section{U.S. Department of the Interior \\ Dirk Kempthorne, Secretary}

\section{U.S. Geological Survey \\ P. Patrick Leahy, Acting Director}

U.S. Geological Survey, Reston, Virginia 2006

Revised and reprinted: 2006

For product and ordering information:

World Wide Web: http:/ / www.usgs.gov/pubprod

Telephone: 1-888-ASK-USGS

For more information on the USGS - the Federal source for science about the Earth, its natural and living resources, natural hazards, and the environment:

World Wide Web: http:/ / www.usgs.gov

Telephone: 1-888-ASK-USGS

Suggested citation:

Stein, R.S., and Lin, J., 2006, Seismic constraints and Coulomb stress changes of a blind thrust fault system, 2: Northridge, California: U.S. Geological Survey Open-File Report 2006-1158, 17 p. [available on the World Wide Web at URL http:/ / pubs.usgs.gov/of/2006/1158/ ].

Any use of trade, product, or firm names is for descriptive purposes only and does not imply endorsement by the U.S. Government.

Although this report is in the public domain, permission must be secured from the individual copyright owners to reproduce any copyrighted material contained within this report. 


\section{Summary}

We review seismicity, surface faulting, and Coulomb stress changes associated with the 1994 Northridge, California, earthquake. All of the observed surface faulting is shallow, extending meters to tens of meters below the surface. Relocated aftershocks reveal no seismicity shallower than $2 \mathrm{~km}$ depth. Although many of the aftershocks lie along the thrust fault and its up-dip extension, there are also a significant number of aftershocks in the core of the gentle anticline above the thrust, and elsewhere on the up-thrown block. These aftershocks may be associated with secondary ramp thrusts or flexural slip faults at a depth of $2-4 \mathrm{~km}$. The geological structures typically associated with a blind thrust fault, such as anticlinal uplift and an associated syncline, are obscured and complicated by surface thrust faults associated with the San Fernando fault that overly the Northridge structures. Thus the relationship of the geological structure and topography to the underlying thrust fault is much more complex for Northridge than it is for the 1983 Coalinga, California, earthquake. We show from a Coulomb stress analysis that secondary surface faulting, diffuse aftershocks, and triggered sequences of moderate-sized mainshocks, are expected features of moderate-sized blind thrust earthquakes.

\section{Analysis of surface faulting}

The 1994 M=6.7 Northridge, California, earthquake struck on a south-dipping blind thrust fault at $17 \mathrm{~km}$ depth, and ruptured to within $6 \mathrm{~km}$ of the ground surface [Fig. 1) [Hauksson et al., 1995]. Twenty-three years before, in 1971, the M=6.7 San Fernando earthquake struck on a

north-dipping, surface-cutting fault, and so the two events appear closely related Fig. 2] [Mori et al., 1995; Tsutsumi and Yeats, 1999]. The 1994 earthquake produced a vigorous aftershock sequence, but none of the mapped active surface thrust or strike-slip faults ruptured at the surface. However, four isolated sites of concentrated secondary surface rupture were observed within $\sim 22 \mathrm{~km}$ of the epicenter [Hecker et al., 1995; Catchings, et al., 1998; Rymer et al., 2001] (Fig. 1).

Mapping of surface faults and associated Holocene alluvial deposits, together with shallow seismic reflection profiling, geodetic leveling surveys and paleoseismic trenching, indicates that all of the faulting is shallow and unlikely to penetrate deeper than several tens of meters [Hecker et al., 1995; Catchings et al., 1998; Rymer et al., 2001]. The central (Granada Hills-Mission Hills) area of surface faulting involved small displacement cracks that reflect control by near-surface conditions. Shallow mass movement in stream deposits and mass wasting on gentle slopes appears to have been triggered by seismic shaking. 
Compressional fractures found along the south side of Potrero Canyon Fig. 3, the northernmost site) are thought to be shallow surficial features developed in or slightly below the soil layer [Rymer et al., 2001]. Trench exposures [Rymer et al., 1995] revealed that these compressional fractures represented slip in the upper $50 \mathrm{~cm}$ of sediment and were antithetic to larger, more deeply extending extensional fractures. Extensional fractures were traced to depths of greater than $6 \mathrm{~m}$ without indication of slip-plane shallowing [Fig. 4) [Rymer et al., 1995]. Crude field estimates of the vertical, compressional, and extensional components of the slip are about $1 \mathrm{~m}$, $0.2 \mathrm{~m}$, and $0.3 \mathrm{~m}$, respectively [Rymer et al., 2001].

We conclude from this review that secondary surface cracking can be expected at least as far as $25 \mathrm{~km}$ away from a M=6.7 blind thrust earthquake, but that such faulting need not extend more than about several meters below the surface.

\section{Analysis of seismicity and fault structure}

In general, blind thrust faults tend to fold the overlying sediments into an anticline that grows in amplitude with cumulative fault slip, and grows in wavelength with increase in the down-dip width of the thrust fault [Stein and King, 1984; Stein and Yeats, 1989]. This simple relationship is complicated at Northridge by the adjacent San Fernando fault, which has thrust sedimentary strata over and deformed the Northridge anticline [Yeats and Huftile, 1995]. Nevertheless, several recent attempts to relocate the aftershocks of the Northridge earthquake have revealed new features of the earthquake process [Carena and Suppe, 2002; Shearer et al., 2005]. Carena and Suppe [2002] plotted a subset of the most clustered earthquakes in a 3D viewer and found new features of the blind fault geometry, including a lateral ramp, or corrugation, in the rupture surface Figs. $5 \mathrm{c}$ and 6), and a slightly listric shape to the fault in cross-section (Fig. 5d). There are also a significant number of clustered aftershocks at shallow depth on the up-thrown block (orange to red shocks in Fig. 5d).

There are some minor horizontal alignments of the shallow seismicity; these could be associated with flexural slip faulting or could indicate the presence of shallow decollement fault surfaces [Baldwin et al., 2000]. Carena and Suppe (2002) used oil industry seismic reflection profiles and well logs to plot seismicity in association with geologic structure. The locations of their three cross-sections are shown in Fig. 7, and the sections are reproduced here in Figs. 8-10. In the central cross-section (Fig. 8), a possible high-angle reverse fault is visible at 4-8 $\mathrm{km}$ depth beneath the Pleistocene deposits and the anticline immediately above the Northridge thrust is very flat and immature, suggesting cumulative fault slip of no more than about $1 \mathrm{~km}$. In the easternmost 
cross-section (Fig. 9), no seismicity extends shallower than $3.5 \mathrm{~km}$ depth, but off-fault seismicity is seen in the core of the anticline, similar to aftershocks of the 1983 Coalinga earthquake [Eaton, 1990], suggestive of high-angle reverse faults in the core of the anticline. The westernmost cross-section (Fig. 10) includes the shallowest off-fault seismicity. Carena and Suppe (2002) interpret this as highlighting a fault-propagation fold ramping from $5 \mathrm{~km}$ to $2 \mathrm{~km}$ depth beneath the San Fernando Valley. But there is no direct evidence for such a flat-lying fault. They also interpret the continuation of the Northridge thrust trend beneath the East Ventura basin as a normal fault, but this is not validated on the basis of focal mechanisms.

We conclude that the Northridge fault is immature and that the anticlinal structure is obscured by the older San Fernando-Sierra Madre thrust system that extends to the surface. There is a concentration of aftershocks in the core of the anticline on the upthrown block. To the west of the rupture, there are aftershocks that reach within $2 \mathrm{~km}$ of the ground surface. These could be caused by flexural slip faulting, or perhaps by shallow ramp thrusts.

\section{Analysis of the mechanics of earthquake triggering}

Over the past decade, we have carried out extensive analysis of stress transfer, focusing on how one earthquake can trigger the next by the transfer of stress [King et al., 1994; Stein et al., 1994; Stein, 1999; Lin and Stein, 2004]. This framework offers insights into how blind thrust faults differ from surface-cutting thrusts in the transfer of stress to the shallow crust.

Coulomb stress triggering calculations suggest that blind thrust faults promote failure in the surrounding crust to a much greater extent than surface-cutting faults (Fig. 11) The principal consequence is that blind thrusts should produce more diffuse and distributed aftershock sequences, and they should be able to trigger slip on shallow secondary reverse faults to a much greater degree than surface-cutting thrust events. Such a relationship is seen among most blind thrust earthquakes [Ekström et al., 1992; Stein and Ekström, 1992; Lin and Stein, 2004]. When applied to the Northridge earthquake, this understanding suggests that it is possible that the observed surface faulting shown in Figs. 1 and 3 was promoted by stress transferred to the surface, as seen in Fig. 12.

When the Coulomb stress is resolved at the ground surface, two large lobes of stress increase are evident, and all of the observed secondary faulting falls into these lobes (Fig. 13). However, this calculation assumes that the crustal stiffness is maintained to the surface. Because sedimentary 
basins are likely much more compliant, some of the high stress would result in low strain. Such complications should be included in future model investigation.

A fundamental feature of blind thrust faulting is the stress transfer along strike that leads to successive earthquake sequences or large off-fault aftershocks. $M \leq 6.8$ blind thrust faults tend to be square in aspect ratio; in other words, their length is similar to their width [Lettis et al., 1997]. Such short faults are highly efficient at increasing the stress beyond the fault ends along strike, whereas long faults increase the stress beyond the ends only slightly more [Lin and Stein, 2004] Fig. 14) In contrast, the region of stress drop is much larger for the long fault. This means that $M \leq 6.8$ blind fault earthquakes are more prone to trigger successive earthquakes on adjacent fault segments than are $M>7$ events, which tend to be much longer along strike in comparison to their width (Fig. 14). This suggests that the moderate size events like the 1994 Northridge earthquake are capable of promoting further moderate size events in the surrounding crust.

Conclusion A key finding of this study is that while secondary surface faulting can occur within $\sim 25 \mathrm{~km}$ of a moderate-size blind thrust mainshock, little if any of this faulting appears to extend beneath a depth of $10 \mathrm{~m}$. While most aftershocks are associated with the main Northridge fault rupture, shallow seismicity is also seen in the core of the anticline and elsewhere on the up-thrown block, extending no shallower than $2 \mathrm{~km}$ depth. The geological structure as revealed by oil well logs and seismic reflection profiles is not simply related to the Northridge thrust fault at depth because of near-by surface thrust faults and possible ramp thrust and decollement faults in the uppermost $4 \mathrm{~km}$. Coulomb stress analysis suggests that blind thrust faults promote failure in the surrounding crust to a much greater extent than surface-cutting faults, thus promoting zones of diffuse aftershocks. The observed surface faulting associated with the 1994 Northridge quake could partly be a consequence of stress transfer to the surface.

Acknowledgments. We thank Suzanne Hecker and Michael Rymer for constructive reviews. This article is based on a project report to the Central Research Institute of Electric Power Industry (CRIEPI), Japan, Sub-Contract Order Number 10504201. 


\section{References}

Baldwin, J. N., K. I. Kelson, and C. E. Randolph (2000), Late Quaternary fold deformation along the Northridge Hills fault, Northridge, California: Deformation coincident with past Northridge blind-thrust earthquakes and other nearby structures? Bull. Seismol. Soc. Amer., 90, doi: 10.1785/0119990056, 629-642.

Carena, S., and J. Suppe (2002), Three-dimensional imaging of active structures using earthquake aftershocks: the Northridge thrust, California, J. Struct. Geol., 24, 887-904.

Catchings, R. D., M. R. Goldman, W. H. K. Lee, M. J. Rymer, and D. J. Ponti (1998), Faulting apparently related to the 1994 Northridge, California, earthquake and possible co-seismic origin of surface creacks in Potrero Canyon, Los Angeles County, California, Bull. Seismol. Soc. Amer., 88, 1379-1391.

Eaton, J. P. (1990) The earthquake and its aftershocks from May 2 through September 30, 1993, in Rymer, M. J. and W. L. Ellsworth, ed., The Coalinga, California, Earthquake of May 2, 1983, U.S. Geol. Surv. Prof. pap. 1487, pp. 113-170.

Ekström, G., R. S. Stein, J. P. Eaton, and D. Eberhart-Phillips (1992), Seismicity and geometry of a 110-km long blind thrust fault, 1, The 1985 Kettleman Hills, California, earthquake, J. Geophys. Res., 97, 4843-4864.

Hauksson, E., L.M. Jones, and K. Hutton (1995), The 1994 Northridge earthquake sequence in California: Seismological and tectonic aspects, J. Geophys. Res, 100, 12,335-12,355.

Hecker, S., D. J. Ponti, C. D. Garvin, T. J. Powers, T. E. Fumal, J. C. Hamilton, R. V. Sharp, M. J. Rymer, C. S. Prentice, and F. R. Cinti (1995), Ground deformation in Granada Hills and Mission Hills resulting from the January 17, 1994, Northridge, California, earthquake, U.S. Geol. Surv. Open-File Rep., 95-62.

Hodgkinson, K. M., R. S., Stein, K. W. Hudnut, J. Satalich, A. Lilje, and J. Richards (1996), Repair and restoration of geodetic infrastructure affected by the 1994 Northridge, California earthquake (including 70-page report, 40" x 60" color map, CD-ROM, and slide-set), U.S. Geol. Surv. Open File Rep., 96-517 [http:/ / geopubs.wr.usgs.gov/open-file/of96-517/fema/ ].

Hudnut, K. W., Z. Shen, M. Murray, S. McClusky, R. King, T. Herring, B. Hager, Y. Feng, P. Fang, A. Donnellan, and Y. Bock (1996), Coseismic displacements of the 1994 Northridge, California, earthquake, Bull. Seis. Soc. Amer., 86, S19-S36.

King, G. C. P., R. S. Stein, and J. Lin (1994), Static stress changes and the triggering of earthquakes, Bull. Seismol. Soc. Amer., 84, 935-953.

Lettis, W. R., D. L. Wells, and J. N. Baldwin (1997), Empirical observations regarding reverse earthquakes, blind thrust faults, and Quaternary deformation: are blind thrust faults truly blind? Bull. Seismol. Soc. Amer., 87, 1171-1198.

Lin, J., and R. S. Stein (2004), Stress triggering in thrust and subduction earthquakes, and stress interaction between the southern San Andreas and nearby thrust and strike-slip faults, J. Geophys. Res., 109, B02303, doi:10.1029/2003JB002607. 
Mori, J., D. J. Wald, and R. L. Wesson (1995), Overlapping fault planes of the 1971 San fernando and 1994 Northridge, California earthquakes, Geophys. Res. Letts., 22, 1033-1036.

Rymer, M. J., T. E. Fumal, D. P. Schwartz, T. J. Powers, F. R. Cinti (1995), Distribution and recurrence of fractures in Potrero Canyon associated with the 1994 Northridge, California earthquake, California Dept. Conservation, Division Mines and Geol., Special Pub. 116, p. 135.

Rymer, M. J. et al. (2001), Surface fractures formed in the Potero Canyon, Tapo Canyon, and McBean Parkway areas in association with the 1994 Northridge, California, earthquake, U.S. Geol. Surv. Misc. Field Studies, MF-2360 [http:/ / geopubs.wr.usgs.gov/map-mf/mf2360/ ].

Shearer, P., E. Hauksson, and G. Lin (2005), Southern California hypocenter relocation with waveform cross-correlation, Part 2: Results using source-specific station terms and cluster analysis, Bull. Seismol. Soc. Am., 95, 904-915, doi:910.1785/0120040168.

Stein, R. S. (1999), The role of stress transfer in earthquake occurrence, Nature, 402, 605-609.

Stein, R. S., and G. E. Ekström (1992), Seismicity and geometry of a 110-km long blind thrust fault, 2, Synthesis of the 1982-85 California earthquake sequence, J. Geophys. Res., 97, 4865-4883.

Stein, R. S., and G. C. P. King (1984), Seismic potential revealed by surface folding: The 1983 Coalinga, California, earthquake, Science, 224, 869-972.

Stein, R. S., G. C. P. King, and J. Lin (1994), Stress triggering of the 1994 M=6.7 Northridge, California, earthquake by its predecessors, Science, 265, 1432-1435.

Stein, R. S., and R. S. Yeats (1989), Hidden Earthquakes, Sci. Am., 260, 48-57, June.

Tsutsumi, H., and R. S. Yeats (1999), Tectonic setting of the 1971 Sylmar and 1994 Northridge earthquake sin the San Fernando Valley. California, Bull. Seismol. Soc. Amer., 89, 1232-1249.

Yeats, R. S., and G. J. Huftile (1995), Oak Ridge fault system and the 1994 Northridge, California, earthquake, Nature, 373, 418-420. 


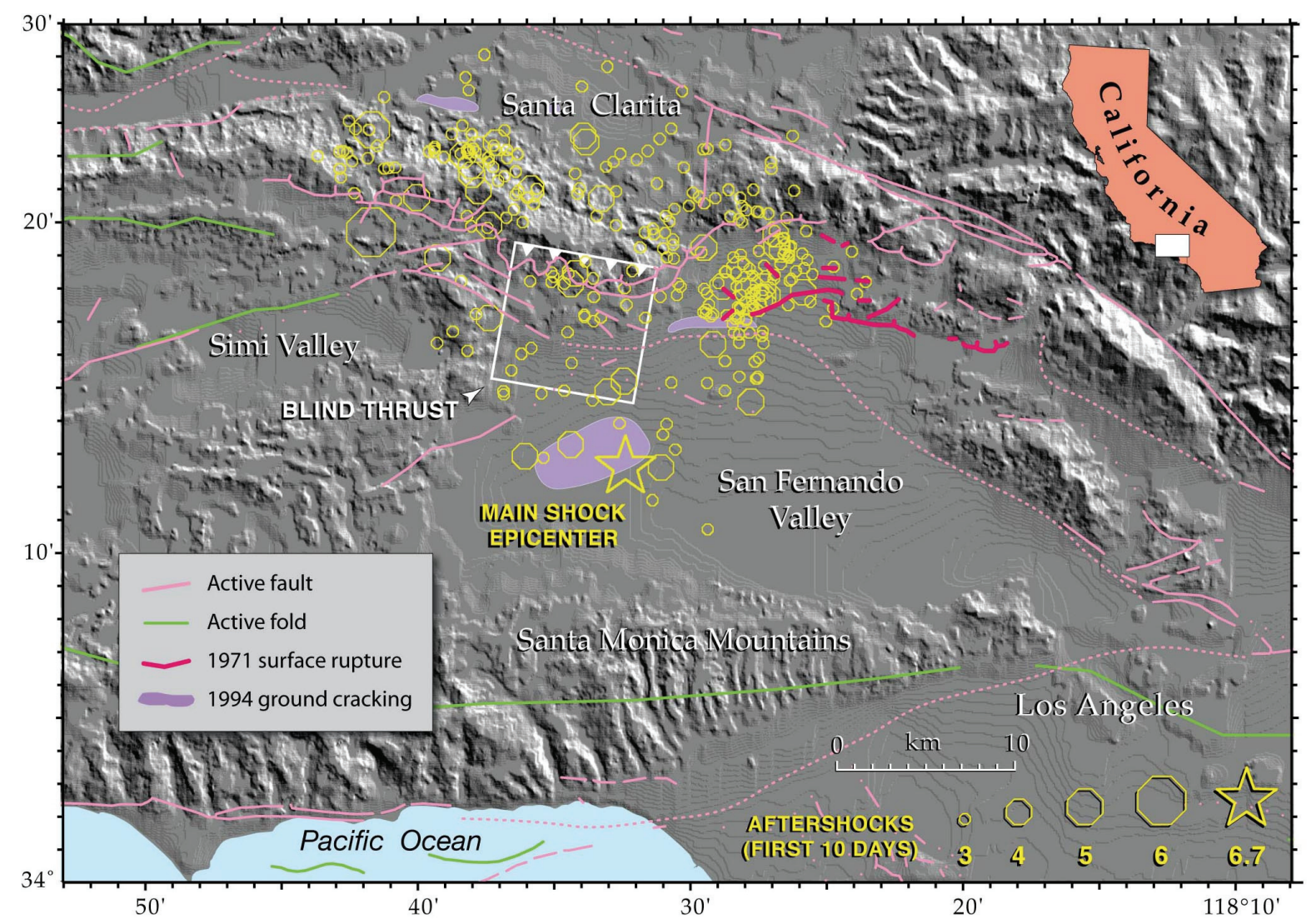

Figure 1. Seismicity, areas of secondary surface rupture (ground cracking), and the principal surface of blind faulting associated with the $1994 \mathrm{M}=6.7$ Northridge earthquake [Hodgkinson et al., 1996]. Red faults ruptured in the $1971 \mathrm{M}=6.7$ San Fernando earthquake.

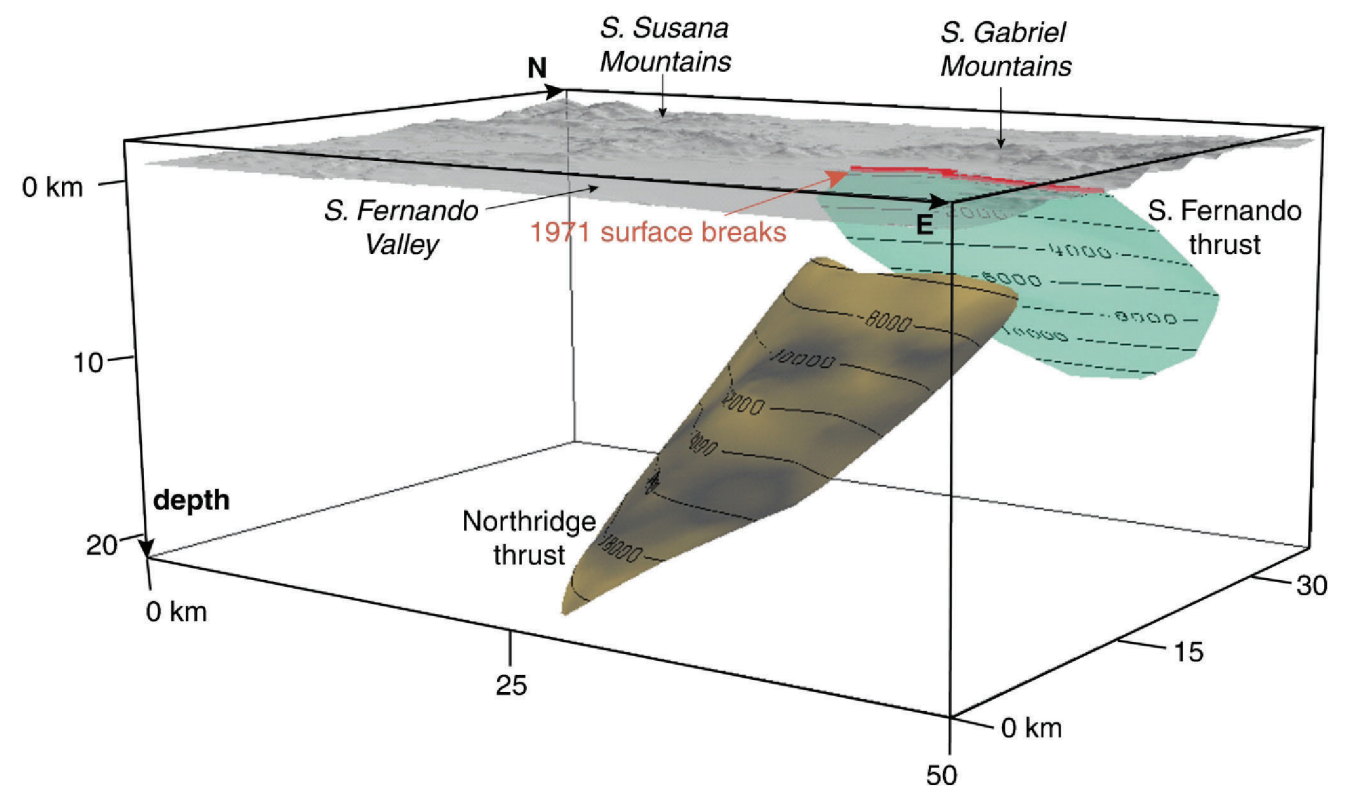

Figure 2. Relationship between the Northridge slip surface (brown) and the 1971 San Fernando slip surface (blue) [Carena and Suppe, 2002]. Depth contours are shown on slip surfaces. 


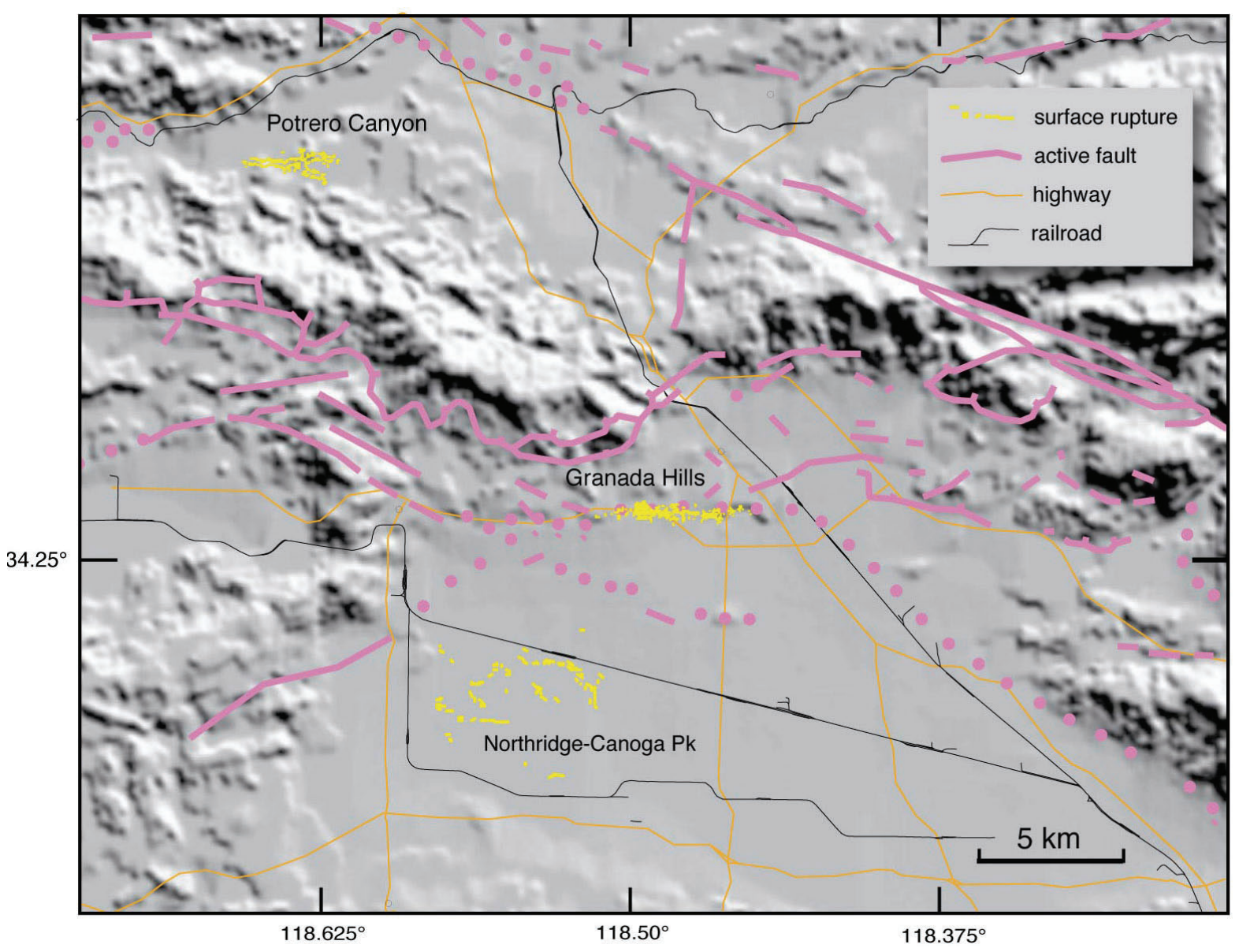

Figure 3. Distribution of secondary surface rupture (short yellow lines) based on [Hodgkinson et al., 1996].

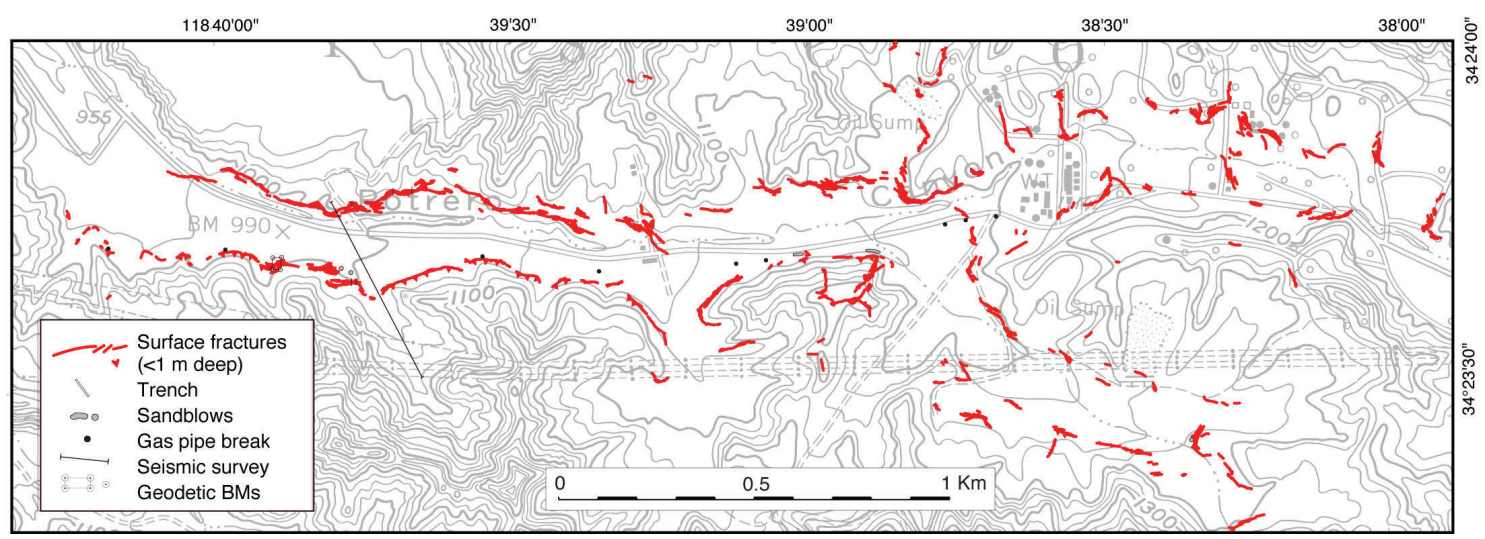

Figure 4. Detailed surface rupture map in the Potero Canyon area [Rymer et al., 2001]. The sense of slip indicates that the canyon floor has subsided relative to its walls. Nearly all of the faults are at bedrock-alluvium contacts, indicating superficial faulting. 


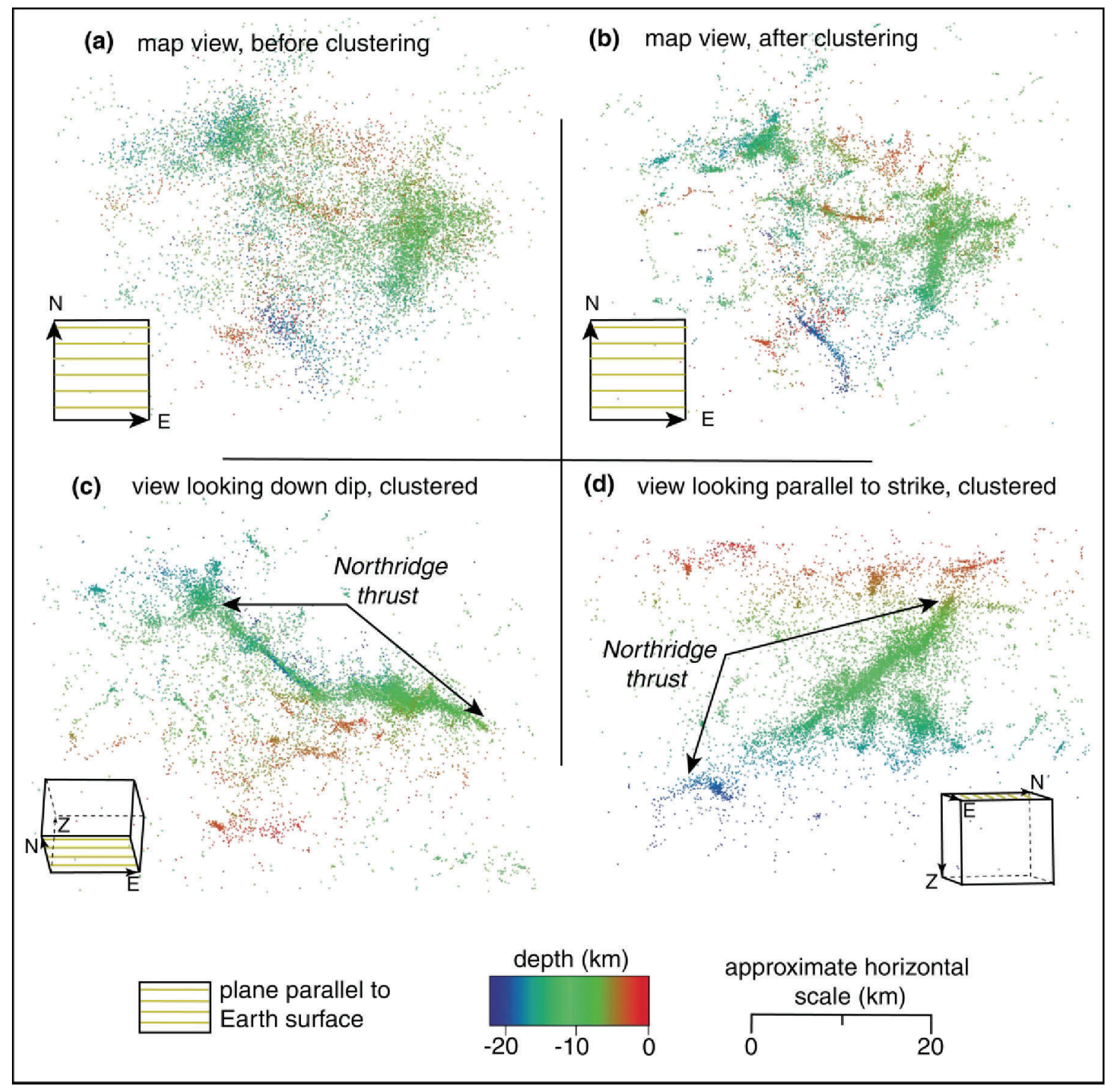

Figure 5. Clustered aftershocks with view rotated to see planar alignments [Carena and Suppe, 2002]. 

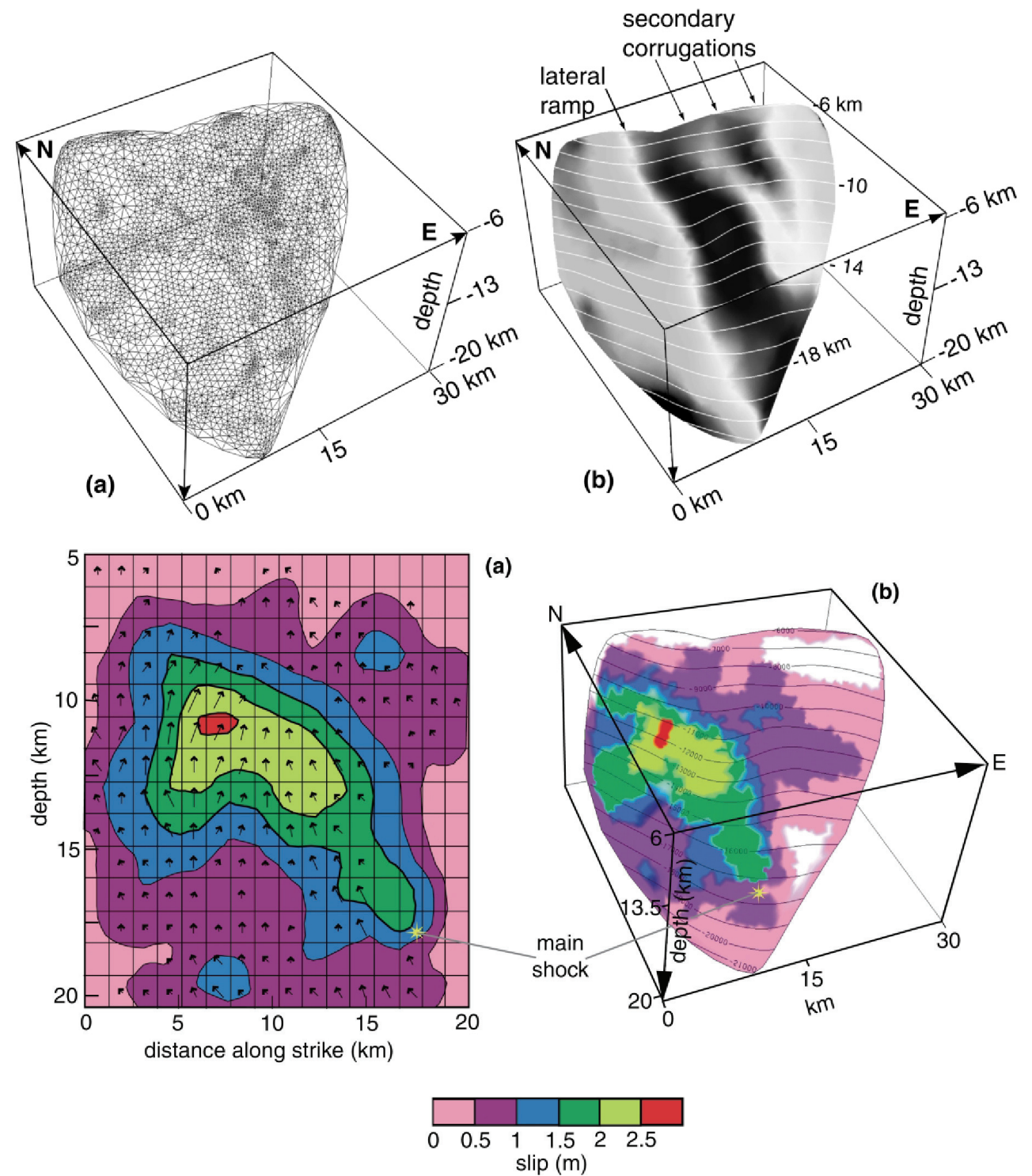

Figure 6. Modeled Northridge fault plane [Carena and Suppe, 2002]. The lateral ramp in the fault is visible in the top right panel. Slip from seismic and geodetic data is shown in the lower panels. 


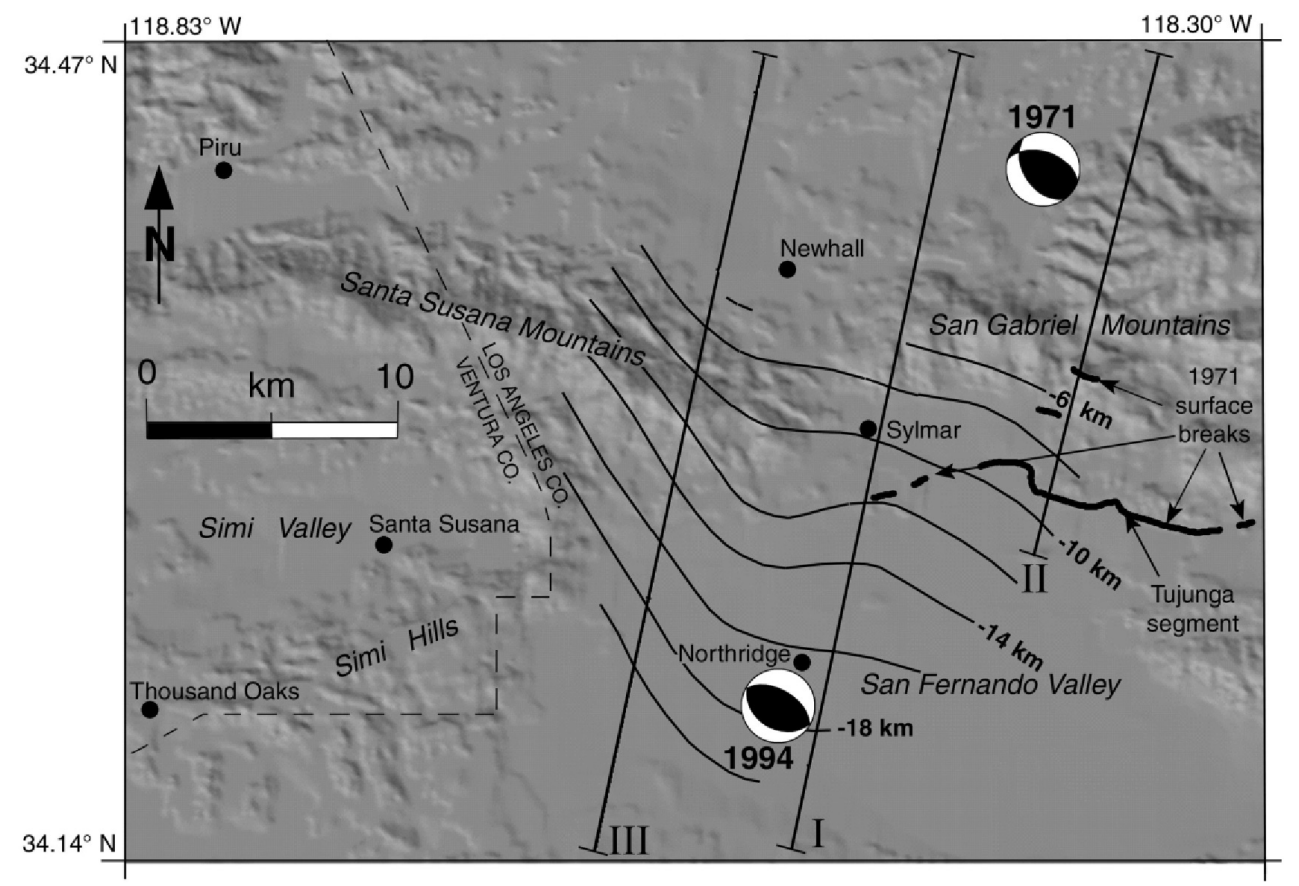

Figure 7. Structural contours on the Northridge rupture surface as interpreted from seismicity data, together with the three cross-sections I-III shown in Figs. 8-10][Carena and Suppe, 2002].

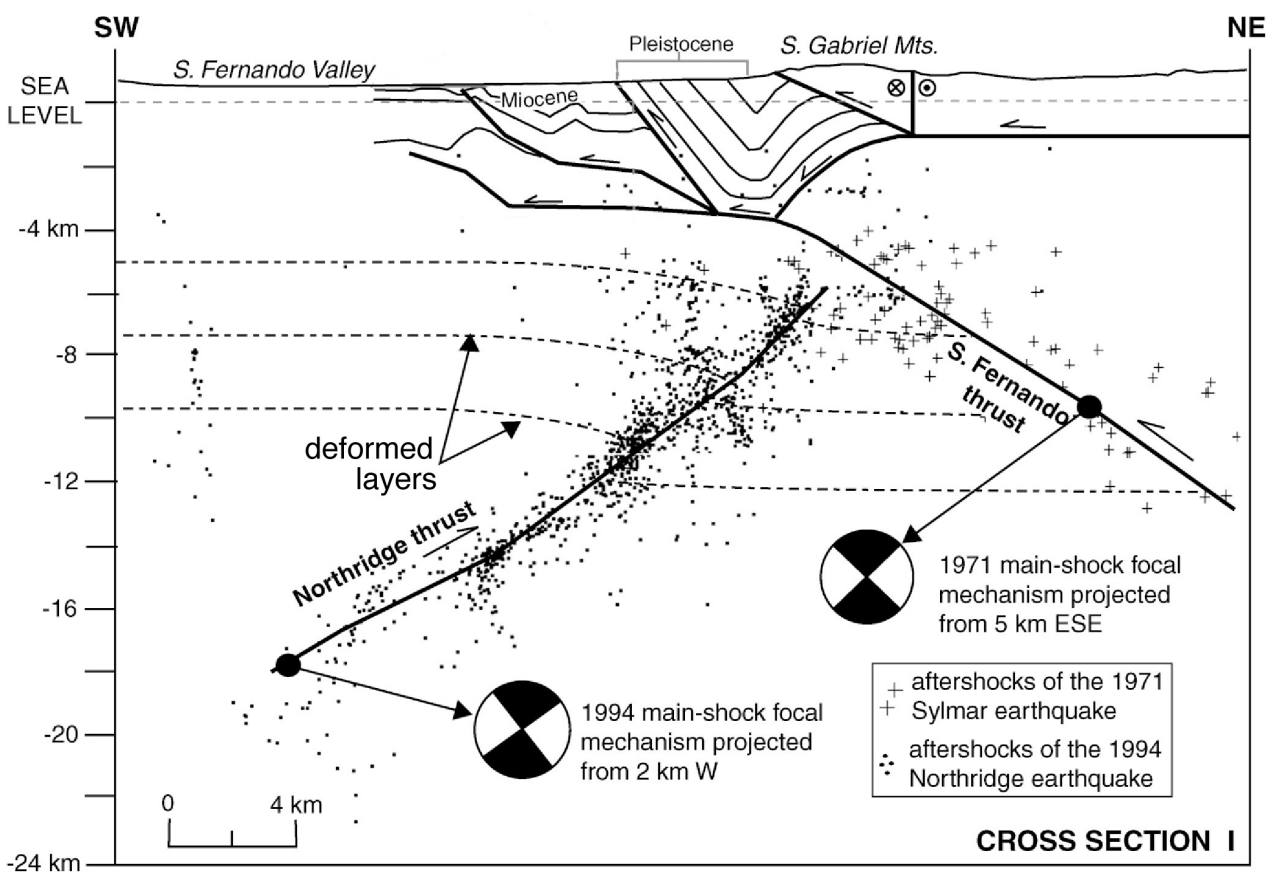

Figure 8. Few shallow aftershocks are seen in the central cross-section [Carena and Suppe, 2002]. A possible high-angle reverse fault is visible above $4 \mathrm{~km}$ depth separating Pleistocene from Miocene deposits (top center). Note as well that the anticline immediately above the Northridge thrust (represented by the uppermost gray dot-dashed line) is very flat and immature, suggesting cumulative fault slip of no more than about $1 \mathrm{~km}$. 


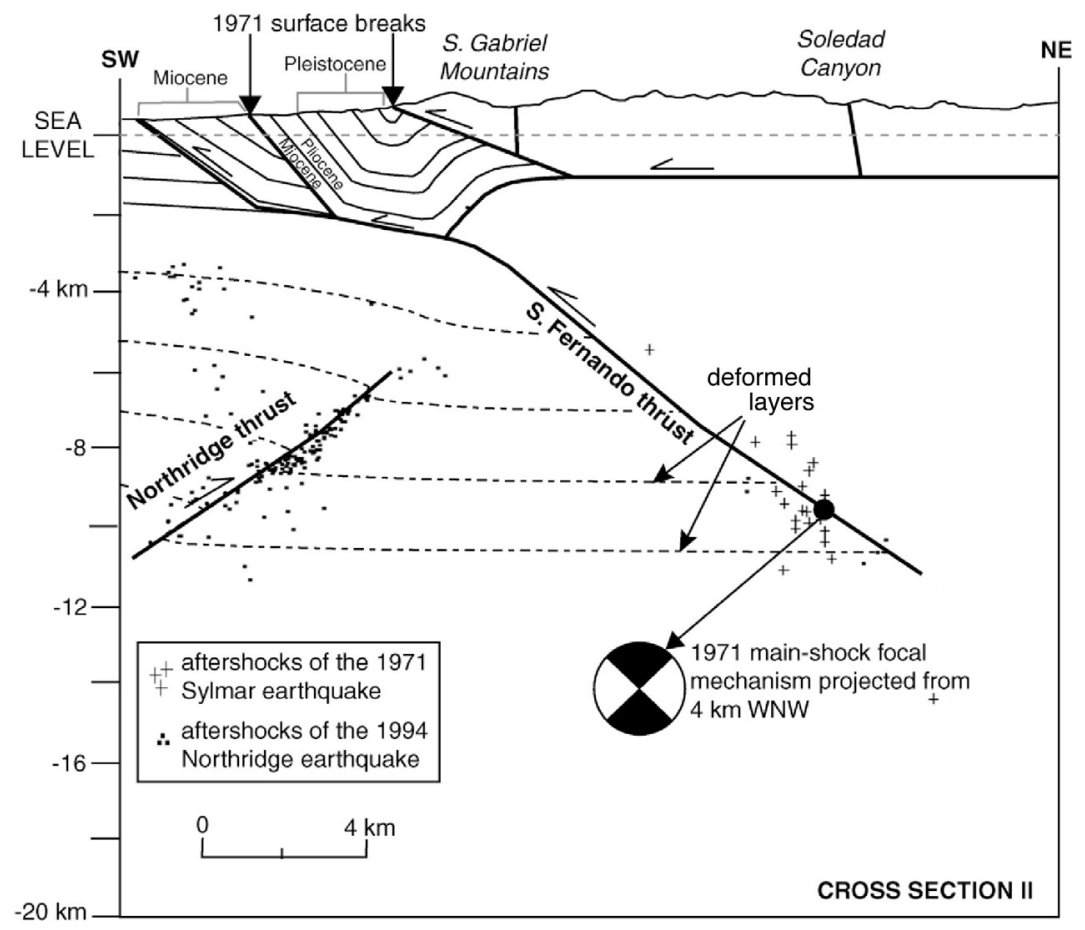

Figure 9. No seismicity extends shallower than $3.5 \mathrm{~km}$ depth in this easternmost cross-section [Carena and Suppe, 2002]. However, off-fault seismicity is seen in the core of the anticline, similar to aftershocks of the 1983 Coalinga earthquake [Eaton, 1990], that we ascribe to high-angle reverse faults in the core of the anticline.

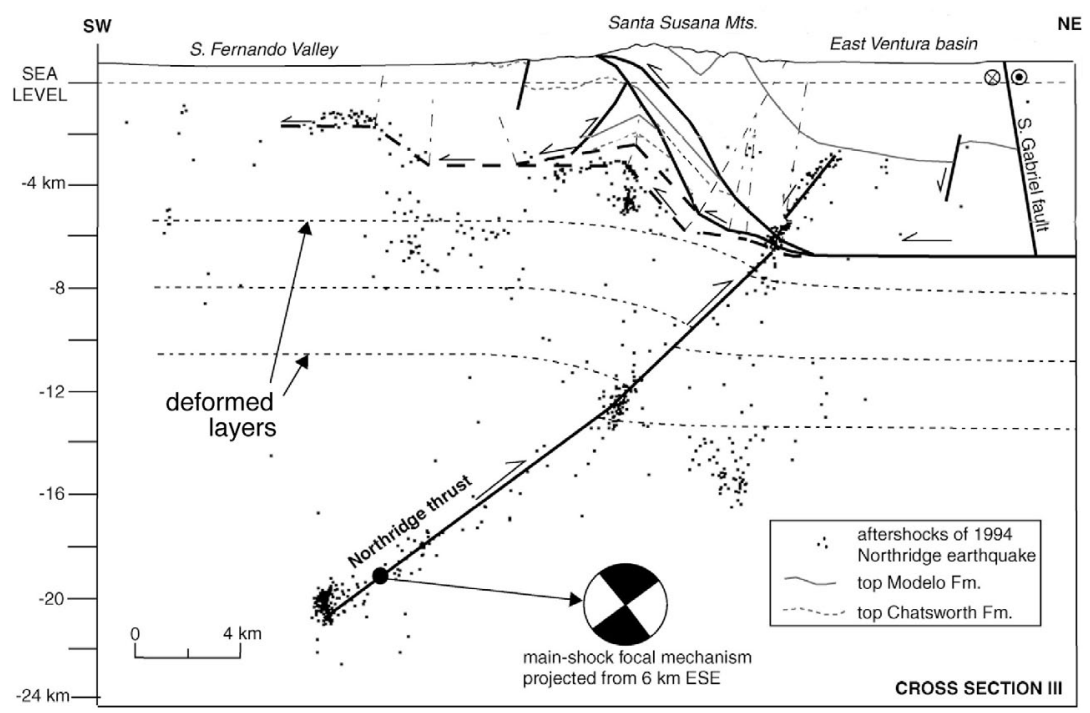

Figure 10. The westernmost cross-section includes the shallowest off-fault seismicity. Carena and Suppe [2002] interpret this as highlighting a fault-propagation fold ramping from $5 \mathrm{~km}$ to $2 \mathrm{~km}$ depth beneath the San Fernando Valley (heavy dashed line). But there is no direct evidence for this feature. They also interpret the continuation of the Northridge thrust trend at 3-6 km depth beneath the East Ventura basin as a normal fault, but this is not validated by focal mechanisms. 

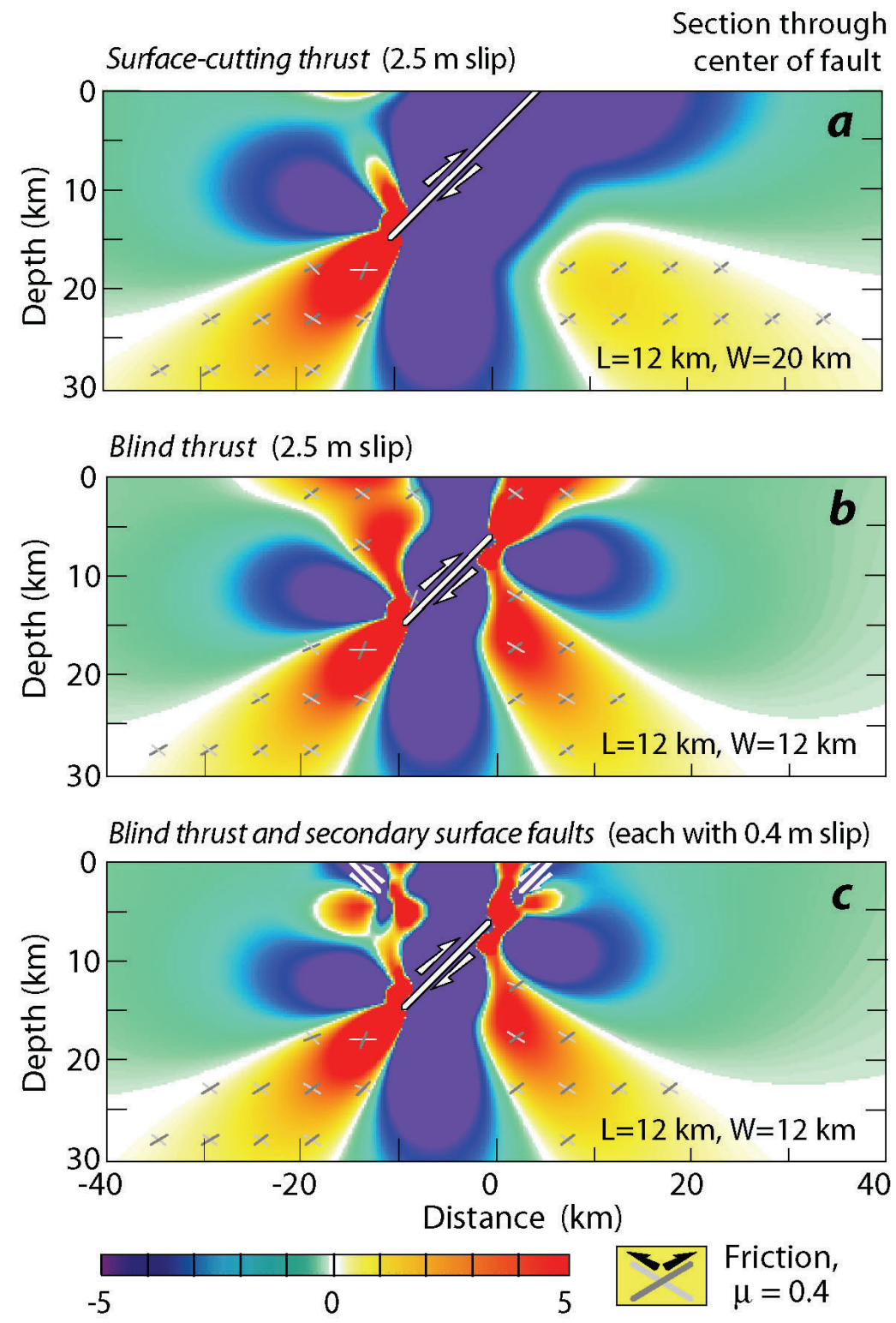

Coulomb stress change (bars) on Optimally oriented optimally oriented thrust faults thrust planes

Figure 11. Cross-sections of the Coulomb stress changes associated with a $45^{\circ}$-dipping thrust fault with $2.5 \mathrm{~m}$ of slip [Lin and Stein, 2004]. In (a), the fault cuts the earth surface as in the 1971 $M=6.7$ San Fernando earthquake, and stress is dropped at almost the entire upper $10 \mathrm{~km}$ in the surrounding crust. In (b), the fault is blind, similar to the $1994 \mathrm{M}=6.7$ Northridge shock, and large near-surface sites of Coulomb stress increase occur. In (c), the near-surface sites of stress transfer are largely removed by slip on shallow, rootless secondary faults [Lin and Stein, 2004]. 


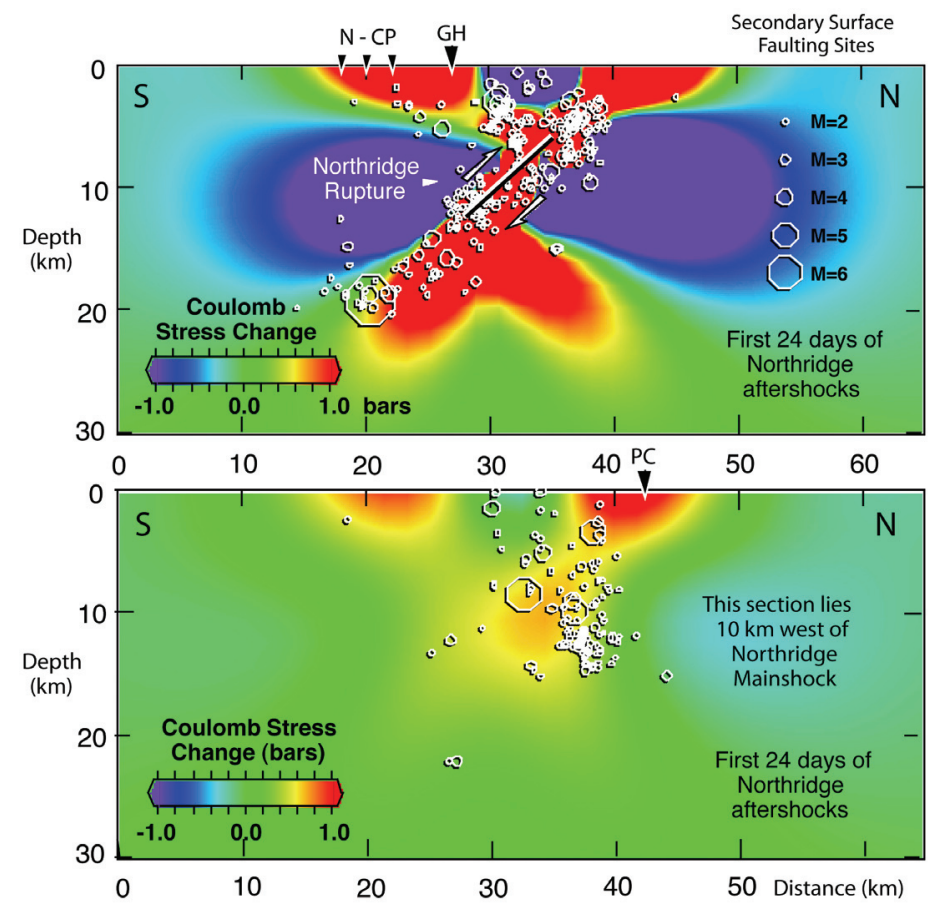

Figure 12. Cross sections of Coulomb stress changes associated with the Northridge earthquake [Stein et al., 1994]. Off-fault aftershocks and sites of secondary surface faulting generally correspond to the Coulomb stress change resolved on optimally-oriented thrust faults. N-CP is Northridge-Canoga Park; GH is Granada Hills (top panel); PC is Potero Canyon (bottom panel). The model parameters are $41.6^{\circ} \mathrm{S}$ dip, 5.84-km burial depth, 10.3-km down-dip width, $8.1-\mathrm{km}$ length, $100^{\circ}$ strike, 3.52-m uniform slip, and $\mathrm{M}_{0}=0.9 \times 10^{26}$ dyne-cm. This model is based on geodetic observations of Hudnut et al. [1996].

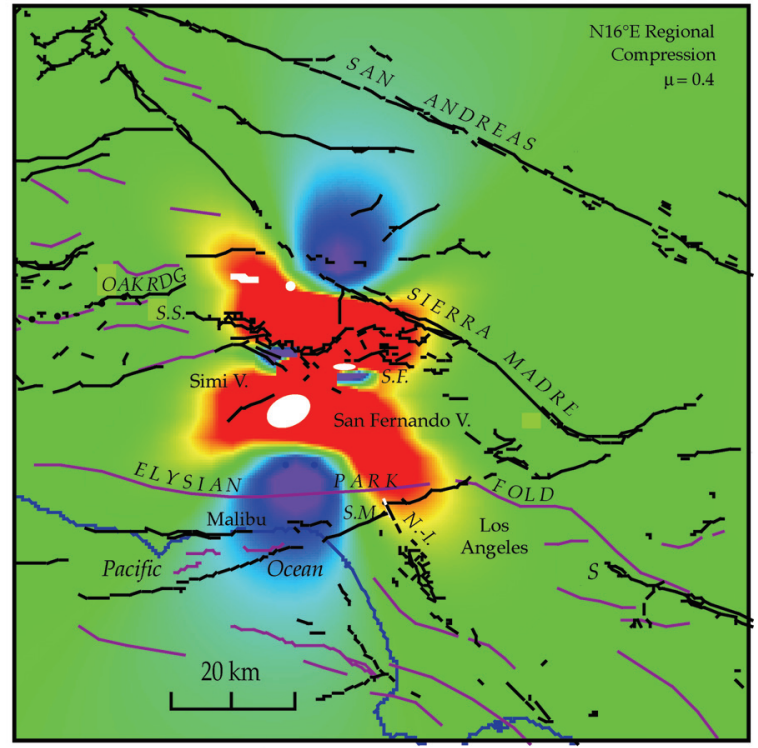

Figure 13. Calculated Coulomb stress change at the ground surface associated with slip on the blind thrust fault in the 1994 Northridge earthquake. Sites of secondary surface faulting are white; they are shown in more detail in Fig. 1 and Fig. 3. 


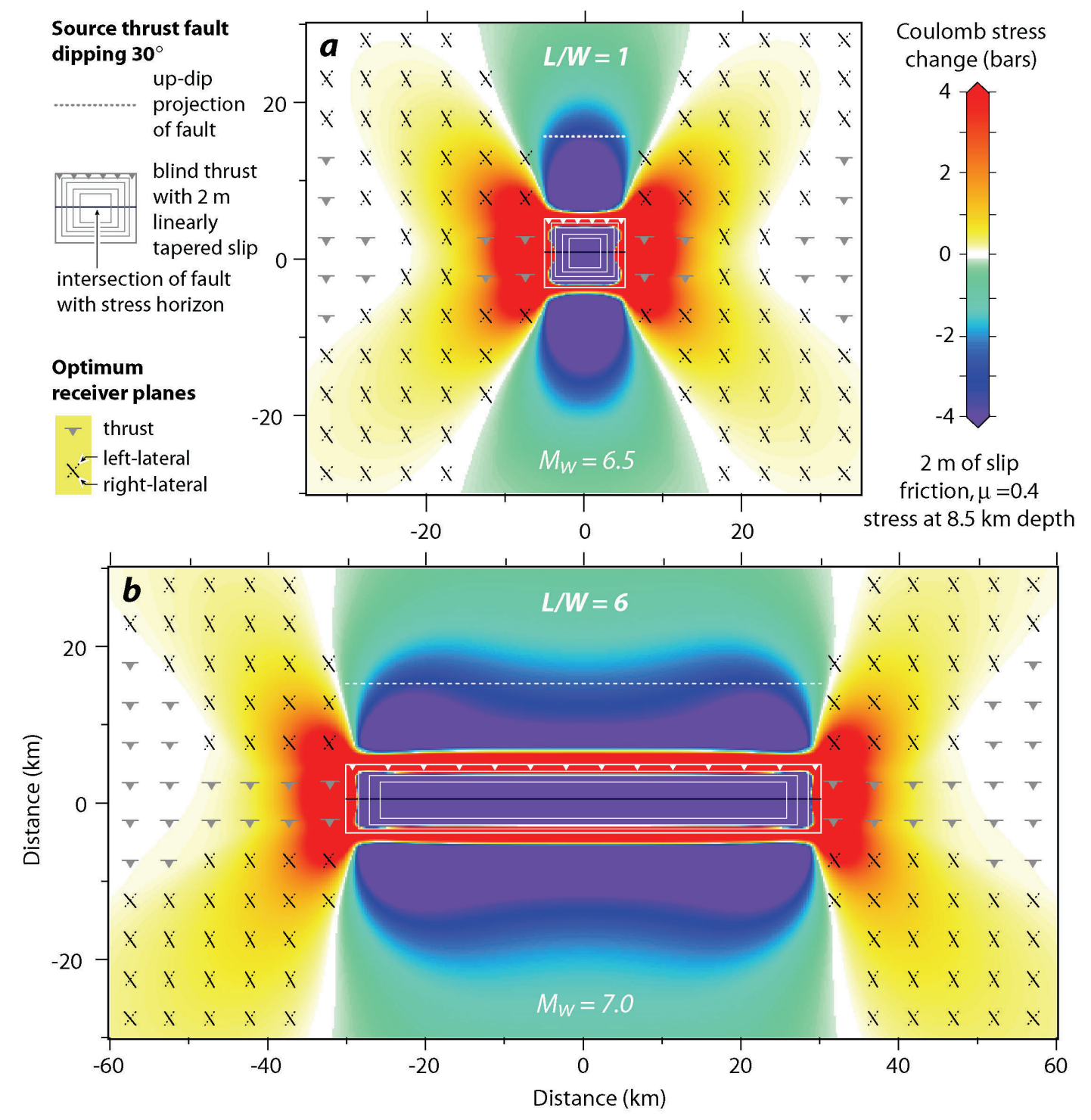

Figure 14. Map view of Coulomb stress changes for $2 \mathrm{~m}$ of slip imposed on a short (a) and long (b) blind thrust fault. The short fault produces nearly as much off-fault stress increases beyond the ends of the rupture (red areas) as does the long fault, but the long fault produces much larger zones of stress decrease [Lin and Stein, 2004]. 